\title{
Sosyal Etki ve Örgütsel Adalet Algısı İlişkisinde Duygusal Bulaşıcılığın Düzenleyici Rolü*
}

\section{The Moderating Role of Emotional Contagion on the Relationship between Social Impact and Organizational Justice}

\author{
Dr. Öğr. Üyesi Esra ZEYNEL (iD) 1 , Dr. Öğr. Üyesi Kemal KÖKSAL (D) 2
}

\begin{abstract}
$\ddot{\mathbf{O} z}$
Örgütsel davranış açısından önemli sonuçları ortaya çıkaran örgütsel adalet kavramının oluşmasında etkili olan faktörlerin belirlenmesi, işyeri tutum ve davranışlarının daha etkin yönetilmesini sağlayacaktır. Bu araştırmada, sosyal etkinin örgütsel adalet algısına etkisi ve bu ilişkide duygusal bulaşma düzeyinin düzenleyici rolü incelenmiştir. Veriler, kolayda örnekleme ve yüz yüze anket metodu ile akademisyenlerden toplanmıştır. Veriler SPSS ve AMOS programları kullanılarak analiz edilmiştir. Ölçekler geçerliliğini test etmek için doğrulayıcı faktör analizi, değişkenler arası ilişkileri incelemek için ise regresyon analizi kullanılmıştır. Analiz sonucunda, sosyal etkiyi kabullenmenin örgütsel adaleti anlamlı bir şekilde yordadığı ve duygusal bulaşıcılığın bu ilişkide düzenleyici rolünün olduğu tespit edilmiştir. Araştırmacı ve uygulayıcılar için önerilerde bulunulmuştur.
\end{abstract}

Anahtar Kelimeler: Sosyal etki, örgütsel adalet, duygusal bulaşıcılık, düzenleyici etki

Makale Türü: Araştırma

\begin{abstract}
Identifying the antecedents of organizational justice which reveals significant result for organizational behaviors can provide effectively manage to employees' attitudes and behavior. In this study, the effect of social impact on the perception of organizational justice and the moderating role of emotional contagion in this relationship were examined. The data were collected from academician by convenience sampling and face-to-face survey methods. SPSS and AMOS programs were used for analysis. Confirmatory factor analysis was used to test the validity of the scales and, regression analysis was performed to investigate the relationships between the variables. As a result of the analysis, it was determined that acceptance of social impact is a predictor of organizational justice and emotional contagion has a moderating role in this relationship.
\end{abstract}

Keywords: Social impact, organizational justice, emotional contagion, moderating effect

Paper Type: Research

\footnotetext{
* Bu çalışmanın ilk hali 18-20.04.2019 tarihlerinde Antalya'da düzenlenen 27.Ulusal Yönetim ve Organizasyon kongresinde bildiri olarak sunulmuștur.

${ }^{1}$ Isparta Uygulamalı Bilimler Üniversitesi, Büyükkutlu Uygulamalı Bilimler Fakültesi, esrazeynel@isparta.edu.tr.

${ }^{2}$ Akdeniz Üniversitesi, Serik İşletme Fakültesi, kemalkoksal@akdeniz.edu.tr.
}

Atıf için (to cite): Esra, Z. ve Köksal, K. (2020). Sosyal etki ve örgütsel adalet algısı ilişkisinde duygusal bulaşıcılığın düzenleyici rolü. Afyon Kocatepe Üniversitesi Sosyal Bilimler Dergisi, 22(2), 455-466. 


\section{Giriş}

Örgütsel etkinlik ve başarının sağlanması, örgüt çalışanlarının performansına bağlıdır. Bir çalışanın performansını iyileştirmenin anahtar faktörleri, artan mesleki motivasyon, iş tatmini, örgütsel bağl1lık, örgütsel vatandaşlık gibi olumlu ve istenen işyeri davranışları ve azalan stres ve işyerinden ayrılma niyeti gibi davranış ve eğilimleri olarak görülebilir. Bilimsel bilgi üreten ve bilgi birikimini kuşaklara aktaran akademik örgütler olan üniversitelerde, akademisyenlerin iş tutumları, üretkenliklerini etkilemekte ve bu sonuçlar eğitim verdikleri kişiler ile birlikte görev yaptıkları üniversitelerin toplam başarısını değiştirebilmektedir (Zeynel ve Çarıkçı, 2015). Örgütsel adalet algısı tüm bu iş tutumları ile ilişsilidir (Dailey ve Kirk, 1992; Colquitt vd., 2001; Moorman, 1991). Bu nedenlerle örgütsel adalet algısının oluşmasında etkili olan faktörlerin anlaşılması çalışan davranışlarının etkin yönetilmesi bakımından önemlidir.

Örgütsel adalet algıs1, her bireyin kendisine özgüdür. Örgütsel ortamdaki uygulamalar, çalışanların bir kısmı tarafından adaletli olarak algılanırken, diğerleri tarafından adaletsiz olarak algılanabilmektedir. Bireyin özgünlüğü ve değerlerine bağlılığı, örgütteki olayları algılamasında belirleyici olabilmektedir (Tyler ve Blader, 2003). Bireyin kendi değerlerine göre yaşaması, onun çevreden gelen baskıları önemsememesi ile ilişkilidir (Wood vd., 2008). Türkiye gibi bireyselliğin düşük, toplulukçu yaşam kültürünün yüksek olduğu ülkelerde, bireylerin tutum ve davranışları örgütteki sosyal etkiyi kabullenmelerine bağlı olarak şekillenebilmektedir. Böyle kültürlerde topluluğun yararı bireyin çıkarından üstün olabilmekte ve grup amaçlarına uyum bireysel başarıdan daha önemli olabilmektedir. Türkiye aynı zamanda, gücün dağıtılmasına ilişkin beklentinin ölçüsü olan güç mesafesinin yüksek olduğu bir kültüre sahiptir. Bu durum, gücün merkezileştirilmesine, yöneticilere ve kurallara güven esasına dayalıdır (Kim vd., 1994; Hofstede vd., 2010). Bu açıdan bireylerin sosyal etkiyi kabullenerek grubun isteklerine göre hareket etmeleri, örgütsel yaşamdaki olayları algılamasında etkili olabilir. Bireylerin diğerlerinden etkilenmesi olarak bilinen sosyal etkiyi kabul etmesinin, örgütsel adalet algısını nasıl etkilediği daha önceki çalışmalarda incelenmemiştir (van den Bosch ve Taris, 2014).

Örgütsel alanlar, bireylerin çalışma yaşamını deneyimledikleri ve çok önemli bir zaman dilimini geçirdikleri alandır. $\mathrm{Bu}$ alanda bireyler çeşitli duygulanımlara sahip olurlar ve duygularını diğer çalışma arkadaşlarına geçirirler ve benzer şekilde diğerlerinden etkilenirler (Doherty, 1997). Duygusal etkileşim düzeyi yüksek olan bireyler, içinde bulundukları toplulukçu ve yüksek güç mesafeli kültüre bağlı olarak diğer çalışanların duygularından daha çok etkilenerek, sosyal etkiyi kabullenmenin örgütsel adalet algısı üzerindeki etkisini artırıcı özelliğe sahip olacaktır. Tam tersi şekilde duygusal bulaşıcılık düzeyi düşük olan çalışanlar, diğerlerinin beklentileri ve bunlara ilişkin duygularından daha az etkileneceğinden, sosyal etkinin örgütsel adalet algısı üzerindeki etkisinin şiddetini artırmayacaktır.

Bu çalışmanın amacı, sosyal etkiyi kabullenmenin örgütsel adalet algısı üzerindeki etkisi ve bu etkide duygusal bulaşıcılığın düzenleyici rolünü araştırmaktadır. Çalışmanın örgütsel adalet algısının oluşmasında daha önce incelenmemiş bir değişken olan sosyal etkiyi kabullenmenin rolünü incelemesi açısından, ilgili alan yazın için önemli olduğu değerlendirilmektedir. Özellikle akademisyenlik gibi bireyin kendilik algısının önemli olduğu bir meslek grubunda (Köksal, 2016) çalışmanın yapılması, akademisyenlerin adalet algısının oluşmasındaki etkenlerin neler olduğuna yönelik anlayışın gelişmesine de katkı sağlayacaktır.

\section{Kuramsal Çerçeve}

\section{1. Örgütsel Adalet ve Sosyal Etki İlişkisi}

Örgütlerde, karşılıklı beklentileri açıklayan ve işyeri davranışını anlamaya yönelik en etkili kavramsal paradigmalardan biri olan Sosyal Değişim Teorisi, sosyoloji (Blau, 1964) ve sosyal psikoloji (Homans, 1958; Thibaut ve Kelly, 1959) disiplinlerinin birleşimini içermekte ve örgütsel adalet (Adams, 1965; Folger ve Greenberg, 1985) kavramının temelini oluşturmaktadır (Cropanzano ve Mitchell, 2005). Adalet kavramı, sosyal değişim teorisinin önemli bir yönüdür. 
Homans'a (1961) göre değişimde bulunan kişiler, yatırımları ile orantılı olarak bir kazanım bekler ve bu beklenti karşılanır ise yapılan dağıtım adaletli olarak algılanır. Sosyal Değişim Teorisi bu yönüyle Adams'ın Eşitlik Teorisine temel oluşturmuştur (Greenberg ve Colquitt, 2005). Bu teoriye göre, bireyler kendilerini, örgüte yaptığı katkı ile diğerlerinin katkısı ve bu katkılara karşılık elde edilen kazanımlar açısından başkaları ile kıyaslama yaparak eşitlik ya da eşitsizlik algisına sahip olur.

Greenberg'e (1987) göre örgütsel adalet, örgüt içinde çalışanların, kendilerine iş yerinde ne kadar adil olarak davranıldığı konusundaki algılarını ve bu algının örgütsel sonuçları nasıl etkilediğini içeren bir kavramdır. Bu açıdan örgütsel adalet, bir çalışanın, örgütte kendisine adaletli davranılmasından çok, bu davranışın kendisi için adaletli olup olmadığına ilişkin algısıdır. Bir başka ifadeyle örgütsel adalet, kazanımların dağıtılmasıyla, dağıtım kararlarının alınmasında kullanılan işlemler ve kişilerarası uygulamalara ilişkin geliştirilen kurallar ve sosyal normlardır (Folger ve Cronpanzano, 1998).

Araştırmalar örgütsel adalet ile çalışan davranışı arasında ilişkiler olduğunu ortaya koymuştur (Colquitt, vd., 2001). Örgütsel adalet kavramı, alanyazında ilk araştırmalarda öne çıkan dağıtımsal adalet (Adams, 1965), prosedürel (Folger ve Greenberg, 1985) ve etkileşimsel adalet (Bies ve Moag, 1986) boyutları ile üç boyutlu olarak (Cohen-Charash ve Spector, 2001; Colquitt, 2001; Cropanzano ve Greenberg, 1997) ve bilgi adaletinin eklenmesiyle dört boyutlu olarak incelenmektedir. Örgütsel adalet, bu çalışmadaki gibi, genel adalet bağlamında tek boyutlu olarak da incelenmektedir (Ambrose ve Schminke, 2009).

Çalışanlar, kendilerine adil davranıldığı algısına sahip olduklarında, örgüte karşı daha pozitif tutum ve davranışlar ile karşılık verme çabasındayken adaletsizlik algısına da olumsuz tutum ve davranışlarla cevap verebilmektedirler (Ganegoda vd., 2015; Bartle ve Hays, 1999; Cohen-Charash ve Spector, 2001; Colquitt, vd., 2001; Rupp ve Cropanzano, 2002; Folger ve Konovsky, 1989; McFarlin ve Sweeney, 1992; Moorman, 1991; Sheppard vd.,1992).

Örgütsel adalete ilişkin olumlu alg1, çalışanların kişisel tatmini ve bununla bağlantılı olarak örgütsel amaçları gerçekleştirmedeki başarısı için temel bir gerekliliktir (Greenberg, 1990). Örgüt genelinde adaletin özenle gözetildiğine ilişkin bir algının oluşturulabilmesi, örgütsel amaçlara ulaşmada yöneticiler açısından önemli bir araçtır (Joy ve Witt, 1992). Bu sonuçların her biri, çalışanların tutum ve davranışlarının örgütlerine kazanım sağlayacak biçimde oluşması açısından, örgütsel adaletin önem arz ettiği görüşünü güçlendirmektedir.

Örgütsel adalet algısını etkileyen unsurlardan biri de kişilerin kendi değerlerine bağlı olması ya da tersine kendinden daha çok grubun amaçlarını önemsemesi ve uzlaşmacı bir yaklaşıma sahip olması özelliği olabilir (Klehe ve Anderson, 2007). Bu açıdan, bireylerin diş çevreden etkilenme düzeyini ifade eden sosyal etkiyi kabullenme, otantiklik kavramının bir boyutudur. Kendine özgülük olarak da ifade edilen otantiklik kavramı, bireyin ilişkilerinde öz benliğini özgür bir şekilde ortaya koyması olarak tanımlanmaktadır (Kernis, 2003). Wood ve arkadaşları (2008), Barrett-Lennard'ın (1998) modelinden yola çıkarak otantikliği üç boyutta ele almışlardır. Otantikliğin birinci boyutu olan kendine yabancılaşma, bireyin gerçek benliği ile bilinçli farkındalığı arasındaki açıklığı ifade etmektedir. Bu açıklık ne kadar fazla ise bireyin kendine yabancılaşma düzeyi de o kadar fazladır. Otantikliğin ikinci boyutu olan otantik yaşam, bireyin değerleri ve inançlarıyla ile davranışları arasındaki uyumu temsil etmektedir. Otantikliğin son boyutu olan sosyal etkiyi kabullenme ise bireyin başkalarının etkilerini kabul etmesini ve onların beklentilerine uygun yaşamasıyla ilgili inançlarını ifade eder. Toplulukçu kültürlerde grupsal adalet, bireysel adaletten daha önemlidir ve grubun iyiliği için bireysel adalet sorgulanmayabilir. Örneğin, toplulukçu kültürlerde terfi kazanmada liyakatten çok kıdemin esas olması çalışanlar tarafindan adaletsiz olarak algılanmayabilmektedir. Otoriteye itaat ve saygı yine bu kültürlerde önemli bir değerdir (Mueller ve Wynn, 2000; Erdoğan ve Liden, 2006) ve hakkaniyete göre paylaşımındansa eşit paylaşım yaygın olarak kullanılmakta ve çatışmadan kaçınılarak uzlaşmacı davranılmaktadır (Kağıtçıbaşı, 1991). Grubun çıkarlarının bireysel 
amaçlardan önde tutulması ve güç mesafesinin yüksek olması gibi nedenlerden, bu kültürlerde, çalışanların sosyal etkiyi kabullenmesinin, örgütsel adalet algılarını etkileyeceği düşünülmektedir. $\mathrm{Bu}$ kapsamda araştırmanın bir numaralı hipotezi aşağıdaki şekilde oluşturulmuştur.

H1: Sosyal etkiyi kabullenme, örgütsel adalet algısını olumlu bir şekilde etkilemektedir.

\subsection{Duygusal Bulaşmanın Düzenleyici Rolü}

Duygular bireylerin algı, tutum ve davranışlarında ve diğer bireylerle kurduğu iletişim süreçlerinde önemli rollere sahiptir. Duygular, belli bir uyaran karşısında genellikle içsel olarak ortaya çıkan ve davranışsal tepkilere yol açan yapılandırılmış izlenimler olarak tanımlanabilir (Kervanc1, 2008). Hatfield ve arkadaşlarına (1994) göre, bireye ait duygular, diğerleriyle olan iletişim şeklini belirleyeceği gibi, iletişimde bulunan bireylerin duyguları, birbirini etkileyebilir ve duygularını başka bir bireye geçirebilirler. Doherty'e (1997) göre, duygusal bulaşma, bir kişide ortaya çıkan duygusal uyaranlarla uyumlu veya tamamlayıcı duygusal tepkiler üreten psikofizyolojik, bilişsel, davranışsal ve sosyal bir durumdur. Duyguların, bireylerin tutum ve davranışlarının temelini oluşturduğu ifade edilmektedir. Çalışanların işe yönelik duyguları kişilerarası etkileşimle diğer çalışanlara bulaşarak, onların tutum ve davranışlarını etkileyebilmektedir (Ashkanasy ve Ashton-James, 2005). Duygusal bulaşma, karşımızdaki insanın yüz ifadesini ve beden duruşunu, farkında olmadan taklit etmek ve bunun sonucunda karşımızdakini duygusal olarak yakınsamak şeklinde tanımlanabilir. (Hatfield vd., 1994). Duyguların bulaşmasının iki aşaması bulunmaktadır. İlk aşamada karşıdaki insanın duygu durumu hakkında istemsiz olarak fikir edinilmesi, ikinci aşamada ise ses tonu, jest ve mimiklerinden duygularının tespit edilmesi söz konusudur (Neumann ve Strack, 2000). Bireylerin bazıları çevresindeki insanların duygularını daha fazla gözlemleyip, o duygulardan etkilenirken; bazı bireylerde ise bu durum düşük olabilmektedir. Bu nedenle duygusal bulaşma düzeyi bireyden bireye farkl11ık gösterebilmektedir (Doherty vd., 1995). Bu kapsamda bireyin sosyal etkiyi kabullenmesinin örgütsel adalet algısına olan etkisinde, duygusal bulaşıcıllı̆ğı yüksek olmasının bu etkiyi şiddetlendireceği öngörülmektedir. Sosyal etkiyi algılayarak bu etkiye göre tutum ve davranışlarını belirleyen bireyin duygusal bulaşıcılık seviyesi bu ilişkide düzenleyici etkiye sahip olabilir. Buraya kadar yapılan teorik açıklamalar ve araştırmalara dayanarak araştırmanın iki numaralı hipotezi aşağıdaki şekilde oluşturulmuştur.

H2: Duygusal bulaşıcılığın yüksek olmas1, sosyal etkinin örgütsel adalete olan etkisinin şiddetini artırmaktadır.

\section{Yöntem}

Çalışmada, bireyin sosyal etkiyi kabul etmesinin örgütsel adalet algısının oluşmasında etkili olup olmadığı, ayrıca duygusal bulaşma seviyesinin bu etkideki düzenleyici rolü incelenmektedir. Değişkenler arasındaki nedensel ilişkiyi açıklamak amacıyla yapılan bu araştırmada veriler kolayda örnekleme yöntemiyle toplanmıştır. Araştırmanın bağımlı ve bağımsız değişkenleri ve demografik bilgiler tek bir anket formunda toplanmıştır. Bu durum ortak yöntem varyans (OYV) sorunu oluşturabileceğinden, bağımsız ve düzenleyici değişkenler anket formunun bir sayfasında yer alırken, değişkenler de farklı katılım dereceleri (beşli ve yedili) ile hazırlanmıştır. Katılımcılara kimlik bilgilerinin istenmediği ve ölçekte yer alan ifadelere cevap verirken, olması gereken durumu değil de mevcut durumu belirtmeleri özellikle belirtilmiştir. Böylelikle OYV sorunu en aza indirilmeye çalışılmıştır (Podsakoff vd., 2003).

OYV problemi, gerçekte var olamayan fakat istatiksel olarak anlamlı nedensel ilişkiler yaratan bir kısıt olduğundan, istatiksel yöntemlerle de kontrol edilmesi gerekmektedir. OYV problemini tespit etmek için farklı yöntemler mevcuttur. Bu çalışmada tüm değişkenler tek bir boyutta toplanarak oluşturulan ölçüm modelinin anlamlılı̆̆ 1 AMOS programı ile kontrol edilmiştir. Analiz sonucunda, oluşturulan modelin anlamlı uyum değerlerine sahip olmadığ görülmüştür (X2=720,530; df:247; GFI:0,653; AGFI:0,543; CFI:0,755; RMSEA: 0,136). Bu 
sonuçlara göre OYV sorununun araştırma için önemli bir kısıt olmadığı değerlendirilmiştir (Hair vd.,2010).

\subsection{Araştırma Modeli}

İlgili alan yazın taraması ve yukarıda bahsedilen kuramlar kapsamında oluşturulan araştırma modeli Şekil 1'de sunulmuştur.

\section{Şekil 1. Araştırma modeli}

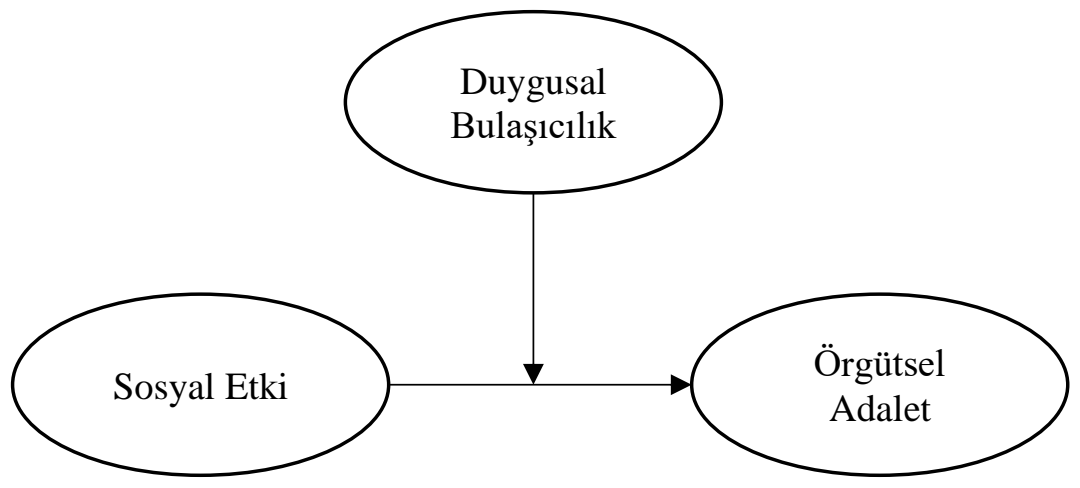

\subsection{Araştırmanın Örneklemi}

Değişkenler arasındaki ilişkiyi test etmek amacıyla iki farklı kamu üniversitesinden kolayda örneklem yöntemiyle, 2018 yılı Ekim-Kasım aylarında, kesitsel olarak 162 veri toplanmıştır. Toplanan verilerden eksik ve uç değerlere sahip olanlar çıkarıldıktan sonra 154 veri ile analiz gerçekleştirilmiştir. Katılımcılara yaş, cinsiyet, eğitim durumu, unvan ve çalışma yılına ilişkin demografik sorular sorulmuştur.

\section{3. Ölçme Araçları}

Katılımcıların sosyal etkiyi kabullenme derecelerini belirlemek amaciyla Wood ve arkadaşları (2008) tarafından geliştirilen ve İlhan ve Özdemir (2013) tarafindan Türkçeye uyarlanan otantiklik ölçeğinin sosyal etkiyi kabullenme boyutu kullanılmıştır. Toplam dört ifadeden oluşan ölçekte "Her zaman başkalarının benden beklentilerini yerine getirmem gerektiğini hissederim." ve "Genellikle başkalarının bana yapmamı söyledikleri şeyleri yaparım." gibi ifadeler yer almaktadır. Ölçekte bir ve yedi arasında katılım dereceleri bulunmaktadır (1=Beni hiç tanımlamıyor, 7=Beni tamamen tanımlıyor). Yüksek puanlar sosyal etkiyi kabul derecesinin yüksek olduğunu göstermektedir.

Örgütsel adalet algısını ölçmek için Ambrose ve Schminke (2009) tarafindan geliştirilen ve araştırmacılar tarafından Türkçeye uyarlanan genel örgütsel adalet ölçeği kullanılmıştır. Yedili Likert kullanılan ölçek (1=Kesinlikle katılmıyorum, 7=Kesinlikle katılıyorum) altı ifadeden oluşan ölçekte "Çalıştığım kurum tarafından baştan sona bana adaletli davranılır." ve "Bu kurum çalışanlarına, büyük ölçüde adil davranır." şeklinde ifadeler yer almaktadır. Yüksek puanlar adalet algısını gösterirken, düşük puanlar adaletsizlik algısına işaret etmektedir.

Duygusal bulaşıcılığı ölçmek amacıyla Doherty (1997) tarafından geliştirilen ve Gürsoy ve arkadaşları (2018) tarafından Türkçe uyarlaması yapılan ölçek kullanılmıştır. Ölçekte sevgi, korku, öfke, mutluluk ve üzüntü olmak üzere beş boyut vardır. Araştırma kapsamında çalışanların genel duygusal bulaşıcılık düzeyleri belirlenmek istendiğinden, ölçeğin 15 ifadeden oluşan ("Konuştuğum biri ağlamaya başlarsa gözlerim dolar." ve "Hiddetli bir tartışmaya kulak misafiri olduğumda gerilirim." gibi) tek boyutlu yapısı kullanılmıştır. Beşli Likertle (1=Kesinlikle katılmıyorum, 5=Kesinlikle katılıyorum) veriler toplanmıştır. Yüksek puanlar yüksek bulaşıcılığ ifade etmektedir. Sosyal etkiyi kabullenme, örgütsel adalet algısı ve duygusal bulaşıcılık 
ölçeklerinin iç tutarlılıklarının iyi seviyede olduğu görülmüştür (Cronbach Alpha değerleri sirasiyla 0,$905 ; 0,937$ ve 0,859$)$.

Ölçeklerin yapı geçerliliği için ise doğrulayıcı faktör analizi, bileşim ve ayrışım geçerliliği analizleri yapılmıştır. Doğrulayıcı faktör analizi sonuçları Tablo 1'de sunulmuştur. Sonuçlar sosyal etkiyi kabul etme ve örgütsel adalet ölçeklerinin tek faktörlü yapılarının iyi uyum değerlerine; duygusal bulaşıc1lık ölçeğinin ise kabul edilebilir uyum değerlerine sahip olduğunu göstermektedir. Sosyal etkiyi kabullenme ölçeğinin ortalama açıklanan varyans (OAV) değeri 0,710 (faktör yükleri: $0,882,0,719,0,866,0,900$ ) ve bileşik güvenilirliği 0,908 'dir. Örgütsel adalet ölçeğinin OAV değeri 0,721 (faktör yükleri: $0,898,0,821,0,868,0,745,0,900,0,855$ ) ve bileşik güvenilirliği 0,939'dur. Duygusal bulaşıc1lık ölçeğinin OAV değeri 0,68 (faktör yükleri 0,495 ile 0,898 arasında değişmekte) ve bileşik güvenilirliği $0,88^{\prime}$ dir. Yapı geçerliliğine ilişkin sonuçlar ölçeklerin ölçülmek istenen değişkenleri ölçmede yeterli olduğunu göstermektedir. Ölçeklerin farklı yapıları ölçüp ölçmediğinin kontrolü ise ayrışım geçerliliği ile yapılmıştır. Araştırmanın değişkenleri tarafından paylaşılan ortak varyans (POV) değerleri OAV değerlerinden düşüktür $\left(\mathrm{OAV}_{\text {Sosyaletki }}=0,710, \mathrm{OAV}_{\text {Adalet }}=0,721, \mathrm{OAV}_{\text {DuygusalB }}=0,680 ; \mathrm{POV}_{\text {Sosyaletki-adalet }}=0,323, \mathrm{POV}_{\text {Sosyaletki- }}\right.$ duygusalB. $\left.=0,230, \mathrm{POV}_{\text {Adalet-duygusalB. }}=0,148\right) . \mathrm{Bu}$ sonuçlara göre ölçeklerin değişik yapıları ölçtüğü ifade edilebilir (Hair vd., 2010). Ölçeklerin geçerli ve güvenilir oldukları görüldükten sonra analizde diğer aşamalara geçilmiştir.

Tablo 1. Doğrulayıcı faktör analizi sonuçları

\begin{tabular}{lllllllll}
\hline Ölçek & $\chi^{2}$ & sd & $\chi 2 /$ sd & RMSEA & CFI & GFI & NFI & RMR \\
\hline $\begin{array}{l}\text { Sosyal Etkiyi } \\
\text { Kabul Etme }\end{array}$ & $3,428^{*}$ & 2 & 1,714 & 0,083 & 0,995 & 0,983 & 0,988 & 0,051 \\
$\begin{array}{l}\text { Duygusal } \\
\text { Bulaşı1c1lk }\end{array}$ & 105,699 & 77 & 1,373 & 0,060 & 0,938 & 0,876 & 0,810 & 0,054 \\
Örgütsel Adalet & $14,153^{*}$ & 9 & 1,573 & 0,074 & 0,990 & 0,955 & 0,974 & 0,070 \\
\hline
\end{tabular}

${ }^{*} p>0,05$

\section{Bulgular}

Ölçeklerin geçerliliği için AMOS, değişkenler arasındaki nedensel ve düzenleyicilik analizi için SPSS programı kullanılmıştır. Geçerlilik analizleri için doğrulayıcı faktör analizleri yapılırken, nedensel ve düzenleyici analiz için korelasyon ve regresyon analizleri yapılmıştır. Değişkenlere ait ortalama, standart sapma ve korelasyon değerleri Tablo 2'de sunulmuştur.

Tablo 2. Ortalama, standart sapma ve korelasyon değerleri

\begin{tabular}{llllll}
\hline Değişkenler & Ort. & S.S. & 1 & 2 & 3 \\
\hline 1- Sosyal Etkiyi Kabul Etme & 2,92 & 0,826 & 1 & & \\
2- Duygusal Bulaşıc1lık & 3,60 & 0,590 & $0,301^{*}$ & 1 & \\
3- Örgütsel Adalet & 3,34 & 0,983 & $0,580^{*}$ & $0,424^{*}$ & 1 \\
\hline
\end{tabular}
${ }^{*} p<0,01$

Değişkenlere ait ortalamalar incelendiğinde sosyal etkiyi kabul etme ve adalet algısının ortalamasının, genel ortalama değerinin (4) altında olduğu görülürken; duygusal bulaşıcılığın ise ortalama değerinin (3) üzerinde ortalamaya sahip olduğu görülmektedir. Katılımcıların sosyal etkiyi kabul etme ve adalet algısı ortalamalarının düşük olduğu ifade edilebilir. Sosyal etkiyi kabul etme ile duygusal bulaşıc1lık arasında düşük pozitif bir korelasyon söz konusuyken, örgütsel adalet algısı ile orta seviyede pozitif korelasyon vardır.

Çalışmanın bir numaralı hipotezini test etmek amacıyla hiyerarşik regresyon analizi yapılmıştır (Tablo 3). Analizin birinci aşamasında demografik değişkenler kontrol değişkeni olarak analize dâhil edilmiştir. Sonuçlara göre demografik değişkenlerden yaş ve unvanın örgütsel adalet algısı üzerinde anlamlı bir etkisi söz konusudur. Katılımcıların yaşı arttıkça örgütlerini 
daha adaletli algılarken, unvan arttıkça bu ilişki ters yönlü olmaktadır. Demografik değişkenler adalet algısındaki değişmenin \%17,4'ünü açıklamaktadır. Hiyerarşik regresyon analizinin ikinci aşamasında ise araştırmanın bağımsız değişkeni olan sosyal etkiyi kabullenme modele dâhil edilmiştir. Bu durumda demografik değişkenlerden yaş, unvan ve çalışma yılının örgütsel adalet algısının oluşmasında anlamlı bir etkisi olduğu görülmüşsür. Sosyal etkiyi kabullenme değişkeni modele dâhil edildiğinde katılımcıların çalışma yılının, örgütsel adalet algısını negatif yönde ve anlamlı bir şekilde etkilediği görülmektedir. Sosyal etkiyi kabullenmenin de örgütsel adalet algısının oluşmasında anlamlı bir etkisinin olduğu da görülmektedir. Bağımsız değişkenin bağımlı değişken üzerindeki değişimi açılama gücü $\% 25^{\prime}$ tir. Bu sonuçlara göre çalışmanın bir numaralı hipotezi kabul edilmiştir.

Tablo 3. Regresyon analizi sonuçları

\begin{tabular}{llllllll}
\hline Örgütsel Adalet & $\beta$ & St. Hata & $\mathrm{t}$ & $\mathrm{p}$ & $\mathrm{F}$ & $\mathrm{R} 2$ & $\Delta \mathrm{R} 2$ \\
\hline 1.Aşama & & & & & & & \\
\hline Sabit & 4,411 & 1,345 & 3,280 & 0,001 & & & \\
Yaş & 0,778 & 0,393 & 1,981 & 0,050 & & & \\
Cinsiyet & $-0,291$ & 0,358 & $-0,815$ & 0,417 & 4,177 & 0,174 & - \\
Eğitim & $-0,422$ & 0,336 & $-1,259$ & 0,211 & & & \\
Unvan & $-0,618$ & 0,191 & $-3,243$ & 0,002 & & & \\
Çalışma Y11 & $-0,298$ & 0,452 &,- 659 & 0,512 & & & \\
2.Aşama & & & & & & & \\
Sabit & 1,018 & 1,232 & 0,826 & 0,411 & & & \\
Yaş & 0,887 & 0,328 & 2,703 & 0,008 & & & \\
Cinsiyet & $-0,126$ & 0,299 & $-0,421$ & 0,675 & & & \\
Eğitim & 0,173 & 0,294 & 0,59 & 0,557 & 12,399 & 0,432 & 0,257 \\
Unvan & $-0,371$ & 0,163 & $-2,271$ & 0,025 & & & \\
Çalışma Y1l1 & $-0,807$ & 0,385 & $-2,099$ & 0,038 & & & \\
Sosyal Etkiyi Kabullenme & 0,576 & 0,086 & 6,660 & 0,000 & & & \\
\hline
\end{tabular}

Çalışmanın iki numaralı hipotezini test etmek maksadıyla düzenleyicilik analizi yapılmıştır. Düzenleyicilik analizinde Hayes (2013) tarafından geliştirilen PROCESS makrosu kullanılmıştır. Analizde bağımsız ve düzenleyici değişkeninin standardize edilmiş değerlerinden, yeni bir etkileşim değişkeni elde edilmekte ve bu değişken modele dâhil edilerek bağımsız değişkenin, bağımlı değişkendeki etkisinin şiddetinin anlamlı bir şekilde artıp artmadı̆̆ görülebilmektedir. Bu kapsamda yapılan düzenleyicilik analizi sonuçları Tablo 4'te sunulmuştur. Sonuçlara göre duygusal bulaşıcılığın sosyal etkiyi kabullenme ile örgütsel adalet ilişkisinde anlamlı bir düzenleyici rolü bulunmaktadır. Düzenleyici etkinin yorumlanabilmesi için ortalama değerlerden bir standart sapma artı ve eksi değerlere göre etki grafiği çizilmesi gerekmektedir. Çizilen etki grafiği incelendiğinde (Şekil 2) duygusal bulaşıcılığın yüksek olması durumunda sosyal etkiyi kabullenmenin örgütsel adalet algısı üzerindeki etkisinin şiddetlendiği görülmektedir. Duygusal bulaşıcılığın durumsal etkisi de incelendiğinde (Tablo 5) duygusal bulaşıcılığın düşük olduğu durumda anlamlı bir etkisinin olmadığı (Ort=3,014, LLCI=-0,244, ULCI $=0,527$ ) ancak duygusal bulaşıcılık seviyesinin artması durumunda \%95 güvenilirlik seviyesinde örgütsel adalet algisı üzerinde sosyal etkiyi kabullenme üzerinden anlamlı bir etkisinin olduğu ve bu etkinin duygusal bulaşıcılık arttıkça arttığ görülmektedir (Ort=3,605, Etki=0,409, LLCI=0,217, ULCI=0,601; Ort=4,196, Etki=0,676, LLCI=0,454, ULCI=0,899). 
Tablo 4. Düzenleyicilik analizi sonuçları

\begin{tabular}{lllllllll}
\hline & \multicolumn{2}{l}{ Örgütsel Adalet } \\
\cline { 2 - 8 } & $\beta$ & SH & p & LLCI & ULCI & F & R2 & $\Delta$ R2 \\
\hline Sabit & 3,225 & 0,134 & 0,000 & 2,959 & 3,491 & & & \\
Sosyal Etki (SE) & 1,064 & 0,252 & 0,000 & 0,564 & 1,565 & & \\
Duygusal Bulaşma (DB) & 0,409 & 0,096 & 0,000 & 0,217 & 0,601 & 36,422 & 0,429 & $0,024^{*}$ \\
SE x DB & 0,452 & 0,213 & 0,036 & 0,029 & 0,876 & & & \\
\hline
\end{tabular}

${ }^{*} p<0,01$, LLCI: Alt sınır güven aralığı, ULCI: Üst sınır güven aralığı

Tablo 5. Sosyal etkiyi kabullenmenin örgütsel adalet üzerindeki etkisinde duygusal bulaşıcıllğın durumsal düzenleyici etkisi

\begin{tabular}{llllll}
\hline $\begin{array}{l}\text { Duygusal } \\
\text { Bulaşicilik }\end{array}$ & Etki & SH & $\mathrm{p}$ & LLCI & ULCI \\
\hline 3,014 & 0,141 & 0,194 & 0,467 & $-0,244$ & 0,527 \\
\hline 3,605 & 0,409 & 0,096 & 0,000 & 0,217 & 0,601 \\
\hline 4,196 & 0,676 & 0,112 & 0,000 & 0,454 & 0,899 \\
\hline
\end{tabular}

LLCI: Alt sınır güven aralığı, ULCI: Üst sınır güven aralığ1

Şekil 2. Etki grafiği

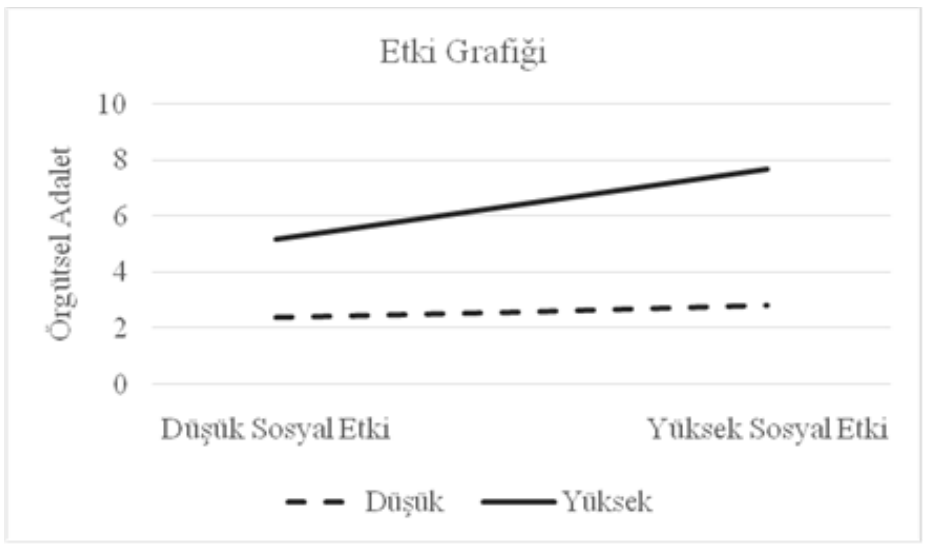

\section{Sonuç, Öneri ve Tartışma}

Akademisyenlerin sosyal etkiyi kabullenme düzeyinin örgütsel adalet algısının oluşumundaki etkisi ve bu ilişkide duygusal bulaşmanın düzenleyici rolünün incelendiği bu araştırmanın sonucunda katılımcıların sosyal etkiyi kabullenme algılarının düşük olduğu görülmektedir. Bu sonucun akademisyenlik mesleğinin doğasından kaynaklanmış olabileceği değerlendirilmektedir. Çünkü akademisyenler bilim üreten insanlar olduğundan onların kendilerine özgün olmaları beklenmektedir. Üniversitelerdeki akademik kültür de bunu destekleyici niteliktedir (Pratt vd., 1999; Köksal, 2016). Katılımciların adalet algısının da ortalamanın altında olması nedeniyle, genel anlamda, örgütlerini adaletsiz olarak algıladıkları ifade edilebilir. Duygusal bulaşıcılık algıları ise ortalamanın üzerindedir. Demografik değiş̧kenlerden yaş ve unvanın örgütsel adalet algısı üzerinde anlamlı etkisi olduğu görülmektedir. Buna göre katılımcılar, yaşları ilerledikçe örgütlerini daha adaletli olarak algılamaktadır. Bu durum kültürel etkiyi doğrular niteliktedir. Toplulukçu ve güç mesafesi yüksek kültürlerde sonuçların dağıtımında kıdem/yaş önemli bir unsur olduğundan (Kim vd., 1994; Kağıtçıbaşı, 1991) yaşa bağlı olarak örgütün adaletli algılanması beklenen bir durumdur. Sosyal etki değişkeni hiyerarşik regresyon modeline dâhil edildiğinde çalışma yılı da örgütsel adalet algısı üzerinde anlamlı bir etkiye sahip olmuştur. Sosyal etkinin çalışma yılı üzerinde baskılayıcı bir etkisi söz konusudur. Ayrıca sosyal etki örgütsel adalet algısını pozitif ve anlamlı bir şekilde etkilemektedir. Katılımcılar sosyal etkiyi kabullendiklerinde örgütsel olayları daha adaletli olarak 
algılamaktadırlar. Bu sonuç toplulukçu kültürün özellikleri ile açıklanabilir. Toplulukçu ve güç mesafesi yüksek kültürlerde bireyler grup çalışmalarına daha yatkın olmakta ve birey merkezli düşük güç mesafesi kültürdeki bireylere göre daha az sosyal kaytarma yapmaktadır (Klehe ve Anderson, 2007). Dolayısıyla toplulukçu ve yüksek güç mesafeli kültürde sosyal etkinin daha fazla olduğu ifade edilebilir. Örgütsel yaşamda yönetim tarafindan alınan kararlar birey tarafindan normal şartlarda adaletsiz olarak algilansa da kararda grubun ya da toplumun yararı vurgulandığında ve çoğunluk tarafından bu karar adaletli olarak nitelendirildiğinde, bireyin sosyal etkiye maruz kalarak durumu adaletli olarak algıladığı düşünülmektedir. Araştırmada duygusal bulaşıc1lık seviyesi yüksek olan bireylerin sosyal etkiyi daha fazla kabul ederek örgütlerini daha adaletli algıladıkları da tespit edilmiştir. Duygusal bulaşıcılık seviyesi yüksek birey, sosyal etki ile duygularından daha fazla etkilenmekte ve örgütsel adalet algisı buna göre şekillenebilmektedir.

Çalışma bulguları, konuyla ilgili araştırmacılar açısından değerlendirildiğinde, sosyal etkiyi kabullenmenin, örgütsel adalet algısının bir önceli olduğunun tespit edilmesi kapsamında ulusal yazına katkı sağladığı değerlendirilmektedir. Ulusal yazınımızda çalışılmamış bir konu olarak, bu çalışmadaki örneklem kapsamında çıkan sosyal etki ile örgütsel adalet ilişkisi, yapılacak diğer çalışmalarla test edilebilir. Çalışma ayrıca akademisyenlerin örgütsel adalet algısının oluşmasındaki nedenlerin daha iyi anlaşılması kapsamında da üniversite yöneticilerine birtakım bilgiler sunmaktadır. Üniversitelerde güçlü bir örgüt kültürü yaratılarak, akademisyenlerin bu örgüt kültürünün oluşturduğu sosyal etkiyi kabullenmesi, onların örgütsel adalet algısını güçlendirebilecektir.

Araştırmanın kısıtları açısından, verilerin kolayda örnekleme yöntemiyle toplanması nedeniyle sonuçlar genellenememektedir. Araştırmada ele alınan değişkenler daha önceki çalışmalarda görgül olarak ele alınmadığından bu sonuçların yapılacak diğer çalışmalarla da test edilmesi gerekmektedir. Bu çalışmada akademisyenlerin sosyal etkiyi kabullenme algısının düşük olması otantikliğin bir göstergesi olarak değerlendirildiğinden, sonraki çalışmalarda akademisyenlerin otantiklik algısı ile akademik performans ilişkisi incelenebilir.

\section{Kaynakça}

Adams, J. S. (1965). Inequity in social exchange. In Berkowitz L (Ed), Advances in Experimental Social Psychology, 2, 267-299. New York: Academic Press.

Ambrose, M. L. ve Schminke, M. (2009). The role of overall justice judgments in organizational justice research: A test of mediation. Journal of Applied Psychology, 49, 491-500.

Ashkanasy, N. M. ve Ashton-James, C. E. (2005). Emotion in organizations: A neglected topic in $\mathrm{I} / \mathrm{O}$ psychology, but with a bright future. International Review of Industrial and Organizational Psychology, 20, 221-268.

Barrett-Lennard, G. T. (1998). Carl Rogers' helping system: Journey and substance. London: Sage.

Bartle, S. A. ve Hays, B. C. (1999). Organizational justice and work outcomes: A meta-analysis. The Annual Meeting of the Society for Industrial and Organizational Psychology, Atlanta, GA.

Bies, R. J. ve Moag, J. S. (1986). Interactional justice: Communicating criteria of fairness. In R. J. Lewicki, B. H. Sheppard, ve M. H. Bazerman (Eds.), Research on negotiation in organizations. 1, 43-55. Greenwich, CT: JAI Press.

Bies, R. J. ve Tripp, T. M. (1996). Beyond distrust: Getting even and the need for revenge. InR.M.Kramer ve T.Tyler (Eds.), Trust in organizations, 246-260. Thousand Oaks, CA: Sage.

Blau, P. M. (1964). Exchange and Power in Social Life. New York: John Wile 
Cohen-Charash, Y. ve Spector, P. E. (2001). The role of justice in organizations: A meta-analysis. Organizational Behavior and Human Decision Processes, 86, 278-321.

Colquitt, J. A. (2001). On the dimensionality of organizational justice: A construct validation of a measure. Journal of Applied Psychology, 86, 386-400.

Colquitt J. A., Conlon D. E., Wesson M. J., Porter C. ve Ng K. Y. (2001). Justice at the millennium: A Meta-analytic review of 25 years of organizational justice research. Journal of Applied Psychology, 86(3), 425-445.

Cropanzano, R. ve Greenberg, J., (1997). Progress in organizational justice: Tunneling through the maze. In C. L. Cooper ve I. T. Robertson (Eds), International review of industrial and organizational psychology, 317-372. New York: Wiley

Cropanzano, R. ve Mitchell, M. S. (2005). Social exchange theory: An interdisciplinary review. Journal of Management, 31, 874-900.

Dirks, K. T. ve Ferrin, D. L. (2002). Trustinleadership: Meta-analytic findings and implications for research and practice. Journal of Applied Psychology, 87, 611-628.

Dailey, R. C., ve Kirk, D. J. (1992). Distributive and procedural justice as antecedents of job dissatisfaction and intent to turnover. Human Relations, 45(3), 305-317.

Doherty, R. W. (1997). The emotional contagion scale: A measure of individual differences. Journal of Nonverbal Behavior, 21(2), 131-154.

Doherty, R. W., Orimoto, L., Singelis, T. M., Hatfield, E., ve Hebb, J. (1995). Emotional contagion: Gender and occupational differences. Psychology of Women Quarterly, 19(3), 355371.

Erdoğan, B. ve Liden, R. C. (2006). Collectivism as a moderator of responses to organizational justice: Implications for leader-member exchange and ingratiation. Journal of Organizational Behavior, 27(1), 1-17.

Folger, R. ve Cropanzano, R. (1998). Organizational justice and human resource management, USA: Sage Publications Inc.

Folger, R. ve Greenberg, J. (1985). Procedural justice: An interpretive analysis of personnel systems. In K. Rowland ve G. Fen-is (Eds), Research in personnel and human resources management, 3, 141-183. Greenwich, CT: JAI Press

Folger, R. ve Konovsky, M. K. (1989). Effects of procedural and distributive justice on reactions to pay raise decisions. Academy of Management Journal, 32(1), 115-130.

Ganegoda, D. B., Latham, G. P. ve Folger, R. (2015). The effect of a consciously set and a primed goal on fair behavior. Human Research Management, 55(5), 89-807.

Greenberg, J. (1987). A taxonomy of organizational justice theories. Academy of Management Review, 12, 9-22.

Greenberg, J. (1990). Organizational justice: yesterday, today and tomorrow. Journal of Management, 16, 399-432.

Greenberg, J. (1993). The social side of fairness: Interpersonal and informational classes of organizational justice. In R. Cropanzano (Ed), Justice in the workplace: Approaching fairness in human resource management, 79-103. Hillsdale, NJ: Lawrence Erlbaum.

Greenberg, J. ve Colquitt, J. A. (Eds). (2005). Handbook of organizational justice. Mahwah, NJ, US: Lawrence Erlbaum Associates Publishers. 
Gürsoy, A., Köksal, K., \& Topcu, M. K. (2018). Etik olmayan örgütsel vatandaşlık davranışının belirleyicileri: Duygusal bulaşıcılığın düzenleyicilik rolü. 26. Ulusal Yönetim ve Organizasyon Kongresi Bildiriler Kitabı (s. 431-439). Karadeniz Teknik Üniversitesi.

Hair, J. F., Black, W. C., Babin, B. J. ve Anderson, R. E. (2010). Multivariate Data Analysis. 7. Edition, New York: Pearson

Hayes, A. (2013). An introduction to mediation, moderation, and conditional process analysis: A regression-based approach. New York: Guilford.

Hatfield, E., Cacioppo ve Rapson, R. (1994). Emotional contagion. New York: Cambridge University Press.

Hofstede, G., Hofstede, G. J. ve Minkov, M. (2010). Cultures and Organizations: Software of the Mind. 3rd ed. b. New York: McGraw-Hill.

Homans, G. C. (1958). Social behavior as exchange. American Journal of Sociology, 63, 597606.

Homans, G. C. (1961). Social behavior: Its elementary forms. New York: Harcourt Brace.

İlhan, T. ve Özdemir, Y. (2013). Otantiklik ölçeğinin Türkçeye uyarlanması: Geçerlik ve güvenirlik çalışması. Türk Psikolojik Danışma ve Rehberlik Dergisi, 5(40), 142-153.

Joy, V. L. ve Witt, L. A. (1992). Delay of gratification as a moderator of the procedural justice distributive justice relationship. Group \& Organization Management, 17, 297-308.

Kağıtçıbaşı, Ç. (1991). İnsan, Aile, Kültür. İstanbul: Remzi Kitabevi.

Klehe, U. C., \& Anderson, N. (2007). The moderating influence of personality and culture on social loafing in typical versus maximum performance situations. International Journal of Selection and Assessment, 15(2), 250-262.

Kernis, M. H. (2003). Toward a conceptualization of optimal self-esteem. Psychological Inquiry, $14,1-26$.

Kervancı, F. (2008). Büro çalışanlarının duygu yönetimi yeterlilik düzeylerinin geliştirilmesinde duygu yönetimi programının etkisi (Yayınlanmamış yüksek lisans tezi). Gazi Üniversitesi, Ankara.

Kim, U., Triandis, H. C., Kağıtçıbaşı, C., Choi, S. ve Yoon, G. (1994). Individualism and collectivism: Theory, method, and applications. London: Sage Publications.

Köksal, K. (2016). Örgüt kültürünün örgütsel adalet algısina etkisinde etik ilkelere ilişkin algıların aracılık rolü (Yayınlanmamış doktora tezi). Celal Bayar Üniversitesi, Manisa.

McFarlin, D. B. ve Sweeney, P. D. (1992). Distributive and procedural justice as predictors of satisfaction with personal and organizational outcomes. Academy of Management Journal, 35, 626-637.

Moorman, R. H. (1991). Relationship between organizational justice and organizational citizenship behaviors: Do fairness perceptions influence employee citizenship? Journal of Applied Psychology, 76, 845-855.

Mueller, C. W. ve Wynn, T. (2000). The degree to which justice is valued in the workplace. Social Justice Research, 1-15.

Neumann, R. ve Strack, F. (2000). Mood contagion: The automatic transfer of mood between persons. Journal of Personality and Social Psychology, 79, 211-223.

Pratt, M., Margaritis, D. ve Coy, D. (1999). Developing a research culture in a university faculty.Journal of Higher Education Policy and Management, 21(1), 43-55. doi:10.1080/1360080990210104 
Podsakoff, P. M., MacKenzie, S. B., Lee, J. Y. ve Podsakoff, N. P. (2003). Common method biases in behavioral research: A critical review of the literature and recommended remedies. Journal of Applied Psychology, 88(5), 879-903.

Rupp, D. E. ve Cropanzano, R. (2002). The mediating effects of social exchange relationships in predicting workplace outcomes from multi-foci organizational justice. Organizational Behavior and Human Decision Processes, 89, 925-946.

Sheppard, B., Lewicki, R. ve Minton, J. (1992). Organizational justice: The search for fairness in the workplace. New York: Lexington Books.

Thibault, J. W. ve Kelley, H. H. (1959). The social psychology of groups. New York: John Wiley.

Tyler, T. R. ve Blader, S. L. (2003). The group engagement model: Procedural justice, social identitity and cooperative behavior. Personality and Social Psychology Review, 7(4), 349-361.

van den Bosch, R.ve Taris, T. (2014). Authenticity at work: Development and validation of an individual authenticity measure at work. Journal of Happiness Studies, 15(1), 1-18. doi: https://doi.org/10.1007/s10902-013-9413-3.

Wood, A. M., Linley, P., Maltby, J., Baliousis, M. ve Joseph, S. (2008). The authentic personality: A theoretical and empirical conceptualization and the development of the authenticity scale. Journal of Counseling Psychology, 55, 385-399.

Zeynel, E. ve Çarıkçı, İ. H. 2015. Mesleki motivasyonun, iş tatmini ve örgütsel bağlllık üzerine etkisi: Akademisyenler üzerine görgül bir araştırma. Süleyman Demirel Üniversitesi İktisadi ve İdari Bilimler Fakültesi Dergisi, 20(3), 217-248.

ETİK ve BİLIMMSEL İLKELER SORUMLULUK BEYANI

$\mathrm{Bu}$ çalışmanın tüm hazırlanma süreçlerinde etik kurallara ve bilimsel atıf gösterme ilkelerine riayet edildiğini yazar(lar) beyan eder. Aksi bir durumun tespiti halinde Afyon Kocatepe Üniversitesi Sosyal Bilimler Dergisi'nin hiçbir sorumluluğu olmayıp, tüm sorumluluk makale yazarlarına aittir. 